\title{
First Report of Micrococcus luteus in the Buccal Cavity of Bearded Dragon (Pogona vitticeps) in Namibia
}

\author{
Paidamoyo N. Mataranyika (D) and Percy M. Chimwamurombe* (D) \\ Natural and Applied Sciences, Namibia University of Science and Technology, Namibia, P. Bag 13388, \\ Windhoek, Namibia.
}

\begin{abstract}
Central bearded dragons, Pogona vitticeps, are ectothermic heliotherms native to dry and arid regions and are often kept as exotic pets in colder less arid countries. They do however, often fall sick resulting in sudden death. This is now known to be caused by bacterial infections such as Listeria monocytogenes and Porphyromonas pogonae sp. This study therefore, aimed to identify microorganisms present in the buccal cavity of the central bearded dragon ( $P$. vitticeps) in Namibia. In order to achieve this, oral swabs were taken from a bearded dragon found in a garden in Windhoek, Namibia and grown in nutrient agar. Colony morphology was described before Gram's staining to differentiate the bacteria. The automated VITEK $^{\circledR} 2$ system was used to identify the bacteria. On nutrient agar, opaque yellow circular colonies were observed after $24 \mathrm{hrs}$ incubation at $37^{\circ} \mathrm{C}$. A gram-positive coccus shaped bacteria was observed. VITEK $^{\circledR 2}$ analysis identified the bacteria as Micrococcus luteus. There has not been a study on the microbiota of the buccal cavity of the central bearded dragon in Namibia.

Keywords: Pogona vitticeps; Micrococcus luteus, buccal microbiota; invasive diseases.
\end{abstract}

*Correspondence: pchimwamurombe@nust.na

(Received: 24 September 2019; accepted: 28 October 2019)

Citation: Paidamoyo N. Mataranyika and Percy M. Chimwamurombe, First Report of Micrococcus luteus in the Buccal Cavity of Bearded Dragon (Pogona vitticeps) in Namibia, J Pure Appl Microbiol., 2019; 13(4):2123-2127. https://doi.org/10.22207/ JPAM.13.4.24

(C) The Author(s) 2019. Open Access. This article is distributed under the terms of the Creative Commons Attribution 4.0 International License which permits unrestricted use, sharing, distribution, and reproduction in any medium, provided you give appropriate credit to the original author(s) and the source, provide a link to the Creative Commons license, and indicate if changes were made. 


\section{INTRODUCTION}

Central bearded dragons, Pogona vitticeps, are ectothermic heliotherms native to dry and arid regions. They are largely herbivorous but may consume insects. When kept as pets, bearded dragons require an optimum diet and living conditions. These include regular water supply and calcium fortified insects ${ }^{1,2}$. Despite optimum conditions, bearded dragons have been known to suffer from anorexia, lethargy and weight loss with symptoms including dehydration and limited reaction ${ }^{3}$. When untreated these cases usually lead to death however, sudden death has occurred in some cases soon after the emergence of signs and symptoms of ill health ${ }^{4}$. Tests done during illness or after death have often revealed gastrointestinal bacterial infections. Porphyromonas pogonae sp. (Porphyromonas spp sometimes known to infect humans as well) and Listeria monocytogenes are some of the common bacterial species found to infect bearded dragons (Fig. 1) ${ }^{2,5}$.

There is also a growing concern in the increase in fungal infections among reptiles. Bearded dragons are most likely to be infected by opportunistic fungi, however dermatomycoses have been noted to be on the rise ${ }^{6}$. On the other hand, adenoviral infections are relatively common among reptiles with the greatest number of cases being reported in bearded dragons ${ }^{7}$. Though the relationship between the bearded dragon and microorganisms is evident not much literature is present on bacterial relations particularly from the oral cavity. To the best of our knowledge, no study has been done to evaluate the oral microbiota of bearded dragons. Therefore, this study aimed

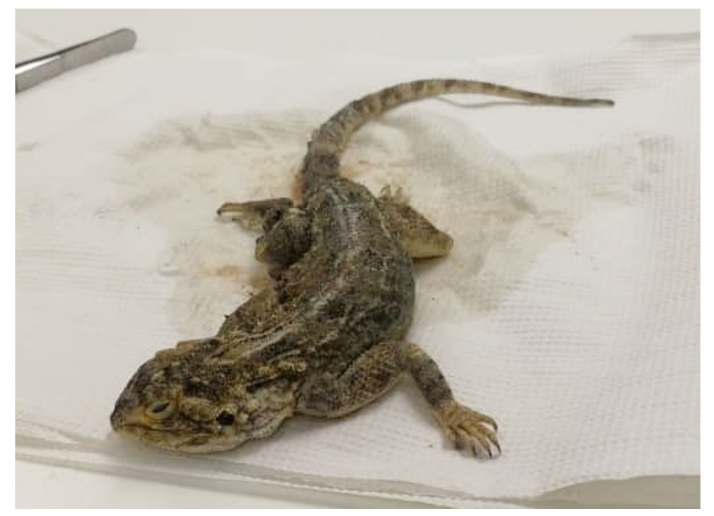

Fig. 1. Central Bearded Dragon (Pogona vitticeps)

Journal of Pure and Applied Microbiology to identify buccal cavity bacteria of the central bearded dragon.

\section{MATERIALS AND METHODS}

\section{Bacterial Isolation}

A central bearded dragon (Fig. 1) found in a garden in Windhoek, Namibia was safely captured and transported in a brown bag to the Namibia University of Science and Technology Natural and Applied Sciences laboratory following the institutional rules for the use of animals in research. Oral swabs were taken from the roof, cheek and tongue oral cavity of the bearded dragon. Swabs were immediately inoculated onto nutrient agar plates and incubated at $37^{\circ} \mathrm{C}$ for 24 hours. The bearded dragon was subsequently released back into the garden. Six selected colonies were sub-cultured onto nutrient agar following a modified description by Kikillus, et al. ${ }^{8}$.

\section{Identification}

Descriptive colony morphology ${ }^{5}$ was done before differential staining using Gram's staining. In order to identify the isolated bacteria, automated biochemical tests were done using VITEK $^{\circledR} 2$ (GP) cards were used depending on the stain result.

\section{VITEK $^{\circledR} 2$ Automated Analysis}

Isolated bacteria samples were recultured on nutrient agar plates at $37^{\circ} \mathrm{C}$ for $24 \mathrm{hrs}$ before VITEK analysis. Thereafter, a few colonies from each sample were suspended in $0.45 \%$ saline solution. An optic density between 0.55 and 0.63 for analysis was preferred. The automated VITEK ${ }^{\circledR} 2$ system performed 43 biochemical tests (Table 1) over a period of $10 \mathrm{hrs}$ using gram-positive VITEK ${ }^{\circledR} 2$ cards.

\section{RESULTS AND DISCUSSION}

The study aimed to identify microorganisms present in the buccal cavity of $P$. vitticeps. The selected colony was observed to be yellow with opaque circular colonies. The colonies had entire edges and raised elevations. Gram-staining showed the cells to be gram positive and coccus shaped, with a few tetrads clustered cells. VITEK ${ }^{\oplus}$ GP analysis identified the bacteria as Micrococcus luteus. Figure 2 shows the colonies on nutrient agar while Table 1 shows a summary of the results.

Micrococcus luteus is a coccus shaped gram-positive bacteria. It is an aerobic 
Table 1. Results summary for M. luteus

\begin{tabular}{|c|c|c|c|c|c|c|c|c|}
\hline ID & \multicolumn{2}{|c|}{ Morphology } & & Gram stain & Shape & \multicolumn{3}{|c|}{ VITEK result } \\
\hline \multirow[t]{2}{*}{ G4.2 } & \multicolumn{3}{|c|}{$\begin{array}{l}\text { Yellow, opaque circular colonies with } \\
\text { raised elevations and entire edges. }\end{array}$} & Positive & \multicolumn{2}{|c|}{ Coccus } & \multicolumn{2}{|c|}{ Micrococcus luteus } \\
\hline & \multicolumn{8}{|c|}{ Biochemical tests } \\
\hline \multicolumn{2}{|c|}{ Reactions } & Result & $\begin{array}{c}\text { Acid } \\
\text { Production }\end{array}$ & Result & $\begin{array}{c}\text { Growth } \\
\text { in } 6.5 \% \\
\mathrm{NaCl}\end{array}$ & Result & $\begin{array}{l}\text { Antibiotic } \\
\text { resistance }\end{array}$ & Result \\
\hline $\begin{array}{l}\text { Phosp } \\
\text { phosp }\end{array}$ & $\begin{array}{l}\text { ti-dylinositol } \\
\text { lipase C }\end{array}$ & & Amygdalin & & $\begin{array}{l}\text { Single } \\
\text { test }\end{array}$ & - & Polymyxin B & + \\
\hline $\begin{array}{l}\text { Argin } \\
\text { (two }\end{array}$ & $\begin{array}{l}\text { dihydrolase } \\
\text { ts) }\end{array}$ & + & Xylose & + & & & Optochin & + \\
\hline$\beta$-galc & osidase & + & $\alpha$-cyclodextrin & + & & & Novobiocin & + \\
\hline$\alpha$-glu & sidase & + & Sorbitol & - & & & 0129 & - \\
\hline $\begin{array}{l}\text { Alanir } \\
\text { prolin }\end{array}$ & $\begin{array}{l}\text { phenylalanine- } \\
\text { arylamidase }\end{array}$ & - & Galactose & & & & Bacitracin & - \\
\hline L-asp & ic acid & & Ribose & + & & & & \\
\hline Aryl-a & dase & & Lactate & & & & & \\
\hline$\beta$-gala & osidase & + & Lactose & + & & & & \\
\hline$\alpha-m a$ & osidase & & $\begin{array}{l}\mathrm{N} \text {-acetyl- } \\
\text { glucosamine }\end{array}$ & + & & & & \\
\hline Alkali & phosphatase & & Maltose & + & & & & \\
\hline L-leuc & aryl-amidase & & Mannitol & + & & & & \\
\hline Prolin & arylamidase & & Mannose & + & & & & \\
\hline $\begin{array}{l}\beta \text {-glu } \\
\text { (two }\end{array}$ & $\begin{array}{l}\text { onidase } \\
\text { ts) }\end{array}$ & & $\begin{array}{c}\text { Methyl- } \beta \text {-d- } \\
\text { glucopy-ranoside }\end{array}$ & - & & & & \\
\hline$\alpha$-gal & osidase & - & Pullulan & - & & & & \\
\hline $\begin{array}{l}\text { L-pyrc } \\
\text { arylar }\end{array}$ & $\begin{array}{l}\text { utamic acid } \\
\text { dase }\end{array}$ & & Raffinose & + & & & & \\
\hline Alanir & arylamidase & & Salicin & + & & & & \\
\hline Tyros & arylamidase & & Sucrose & + & & & & \\
\hline Andu & & & Trehalose & + & & & & \\
\hline
\end{tabular}

Table 1 also indicates the biochemical test results [10-12].

exopolysaccharide producing bacteria that may be found on the skin, mouth and sometimes in the throat of mammals ${ }^{13,14}$. Oral microbial flora of reptiles includes bacteria from Proteus, Porphyromonas, Micrococcus, Salmonella and Staphylococcus genera ${ }^{5,8,15}$. Variations, however, may be present among bearded dragons depending on the diet based on whether they are kept as pets (captive) or in the wild ${ }^{16}$. As such, the oral cavity of snakes and other reptiles alike are more often than not infected by aerobic bacteria ${ }^{17}$.

Described species of Micrococcus are often responsible for invasive diseases such as pneumonia, peritonitis and endocarditis among others $^{18}$. M. luteus has been isolated from the surface of human skin, water and soil ${ }^{19}$. It has been noted to be an opportunistic bacterium and immunocompromised patients pose the greatest risk of infection ${ }^{20,21}$. Treatment of $M$. luteus infection typically involves the use of antibiotics such as penicillin, vancomycin and gentamicin ${ }^{22}$. Cefoxitin has also been successfully used to treat peritonitis as a result of $M$. luteus infection ${ }^{23}$. The pathogenicity of $M$. luteus is not only of concern to humans. Swabs were collected from crocodiles which were dying suddenly on a crocodile farm. 


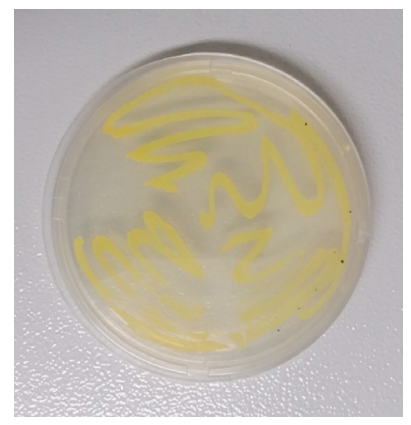

Fig. 2. Micrococcus luteus on nutrient agar

Strains including those of $M$. luteus isolated from the crocodiles dying suddenly were identified as being pathogenic. Though another bacterium (Edwardsiella tarda) caused death, the presence of $M$. luteus and other species contributed to ill health ${ }^{24}$.

This is of particular concern as domestic reptiles kept as pets harbor pathogenic bacteria which may be transferred to humans. Bacteria from the Salmonella species, though intestinal, are the most common pathogens associated with captive reptiles. This runs the risk of infecting other pets within the same household ${ }^{15}$. Bacterial pathogens in the oral cavity of bearded dragons becomes of great concern in the event that a bite occurs. Lizard bites rarely occur as there are limited human-lizard interactions. However, bacterial infections from lizard bites can occur with one such case being fatal as a result of septicemia ${ }^{25}$. The same concern is raised in snakes as venom is not the only challenge presented by venomous snakes. As such bacterial infections are often reported following snake bite incidents in cases were the patient survives the bite ${ }^{16,17}$.

\section{CONCLUSION}

Central bearded dragons harbor aerobic bacteria in their oral cavity, some pathogenic. In this study $M$. luteus was identified in the buccal cavity of $P$. vitticeps. Currently, there are no reported cases on bearded dragon bites on humans. However, they are often kept as pets with close interactions with humans therefore, caution should be exercised when handling them, cleaning their cages and feeding them to prevent the possibility of contracting $M$. luteus. Future work with regards to the $P$. vitticeps could include identifying more microorganisms from the buccal cavity and gut with special attention to possible pathogenicity.

\section{ACKNOWLEDGEMENTS}

The authors acknowledge Dr Renatus Peter Shilangale for allowing access to his Laboratory.

\section{CONFLITS OF INTEREST}

The authors declare that there is no conflict of interest.

\section{AUTHOR'S CONTRIBUTION}

All authors listed have made a substantial, direct and intellectual contribution to the work, and approved it for publication.

\section{FUNDING}

Support from Namibia University of Science and Technology is acknowledged. The grant number is S102.

\section{DATA AVAILABILITY}

All datasets generated or analyzed during this study are included in the manuscript.

\section{ETHICS STATEMENT}

This article does contain studies with animals performed by the authors in a humane way following approved guide lines by our institutional Ethics committee.

\section{REFERENCES}

1. Oldfield CL. Bearded Dragons: Common Husbandry and Nutrition-Related Problems. Vet Nurs J. 2014;29(11): 354-7. https://doi.org/10.1111/vnj.12190

2. Matt $\mathrm{CL}$, Ramachandran $\mathrm{A}$, Allison RW, Wall $\mathrm{CR}$, Dieterly AM, Brandao J. Listeria monocytogenes in an Inland Bearded Dragon (Pogona vitticeps). J. Exot. Pet. Med., 2019; 30: 76-81. https://doi.org/10.1053/j. jepm.2018.12.005

3. Collins SN. Diagnostic Challenge: Gastric Neuroendocrine Carcinoma in a Bearded Dragon (Pogona vitticeps). J. Exot. Pet. Med. [Internet], 2019; 30: 7-11. https://doi.org/10.1053/j.jepm.2018.09.001

4. Schilliger L, Veronique M, Marschang RE, Nicolier A, Richter B. Triple infection with agamid adenovirus 1, Encephaliton cuniculi-like microsporidium and enteric coccidia in a bearded dragon (Pogona vitticeps). Tierarztl Prax Ausgabe K Kleintiere - Heimtiere., 2016; 44(5): 1-4. https://doi.org/10.15654/TPK-150790

5. Kawamura Y, Kuwabara S, Kania SA, Kato H, Hamagishi $\mathrm{M}$, Fujiwara N, et al. Porphyromonas pogonae sp. nov., an anaerobic but low concentration oxygen adapted 
coccobacillus isolated from lizards (Pogona vitticeps) or human clinical specimens, and emended description of the genus Porphyromonas Shah and Collins 1988. Syst. Appl. Microbiol. [Internet], 2015; 38(2): 104-9. https://doi.org/10.1016/j.syapm.2014.11.004

6. Schmidt V. Fungal Infections in Reptiles-An Emerging Problem. J. Exot. Pet. Med. [Internet], 2015; 24(3): 267-75. https://doi.org/10.1053/j.jepm.2015.06.014

7. Hyndman TH, Howard JG, Doneley RJ. Adenoviruses in free-ranging Australian bearded dragons (Pogona spp.). Vet. Microbiol. [Internet], 2019; 234: 72-6. https://doi.org/10.1016/j.vetmic.2019.05.014

8. Kikillus KH, Gartrell BD, Motion E. Prevalence of Salmonella spp., and serovars isolated from captive exotic reptiles in New Zealand. N.Z. Vet. J. 2011; 59(4): 174-8. https://doi.org/10.1080/00480169.2011.5792 46

9. Khalid M, Hassani D, Bilal M, Butt ZA, Hamayun M, Ahmad $A$, et al. Identification of oral cavity biofilm forming bacteria and determination of their growth inhibition by Acacia arabica, Tamarix aphylla L. and Melia azedarach L. medicinal plants. Arch. Oral. Biol. [Internet], 2017; 81: 175-85. https://doi. org/10.1016/j.archoralbio.2017.05.011

10. Bascomb S, Manafi M. Use of enzyme tests in characterization and identification of aerobic and facultatively anaerobic gram-positive cocci. Clin. Microbiol. Rev., 1998; 11(2): 318-40. https://doi. org/10.1128/CMR.11.2.318

11. Funke G, Funke-Kissling P. Performance of the new VITEK $2 \mathrm{GP}$ card for identification of medically relevant gram-positive cocci in a routine clinical laboratory. J. Clin. Microbiol., 2005; 43(1): 84-8. https://doi. org/10.1128/JCM.43.1.84-88.2005

12. Wallet F, Loiez C, Renaux E, Lemaitre N, Courcol RJ. Performances of VITEK 2 colorimetric cards for identification of gram-positive and gram-negative bacteria. J. Clin. Microbiol., 2005; 43(9): 4402-6. https://doi.org/10.1128/JCM.43.9.4402-4406.2005

13. Pekala A, Pazdzior E, Antychowicz J, Bernad A, Glowacka H, Wiecek B, et al. Kocuria rhizophila and Micrococcus luteus as emerging opportunist pathogens in brown trout (Salmo trutta Linnaeus, 1758) and rainbow trout (Oncorhynchus mykiss Walbaum, 1792). Aquaculture, 2018; 486: 285-9. https://doi.org/10.1016/j.aquaculture.2017.12.028

14. Garcia-Sanchez AM, Machado-Moreira B, Freire M, Santos R, Monteiro S, Dias D, et al. Characterization of microbial communities associated with ceramic raw materials as potential contributors for the improvement of ceramic rheological properties. Minerals, 2019; 9(316). https://doi.org/10.3390/ $\min 9050316$
15. Ebani VV. Domestic reptiles as source of zoonotic bacteria: A mini review. Asian Pac. J. Trop. Med. [Internet]. 2017; 10(8): 723-8. https://doi. org/10.1016/j.apjtm.2017.07.020

16. Artavia-Leon A, Romero-Guerrero A, Sancho-Blanco C, Rojas N, Umana-Castro R. Diversity of Aerobic Bacteria Isolated from Oral and Cloacal Cavities from Free-Living Snakes Species in Costa Rica Rainforest. Int. Sch. Res. Not., 2017; 2017: 1-9. https://doi. org/10.1155/2017/8934285

17. Dehghani R, Sharif MR, Moniri R, Sharif A, Kashani HH. The identification of bacterial flora in oral cavity of snakes. Comp Clin Path., 2016; 25(2): 279-83. https:// doi.org/10.1007/s00580-015-2178-9

18. Hetem DJ, Rooijakkers SHM, Ekkelenkemp MB. Staphylococci and Micrococci. In: Cohen J, Powderly WG, Opal SM, editors. Infectious Diseases. Elsevier, 2017. p. 1509-1522.e2. https://doi.org/10.1016/B9780-7020-6285-8.00176-3

19. Yang S, Sugawara S, Monodane T, Nishijima M, Adachi Y, Akashi S, et al. Micrococcus luteus Teichuronic Acids Activate Human and Murine Monocytic Cells in a CD14and Toll-like Receptor 4-dependent Manner. Infect Immun. 2001;69(4):2025-30. http://doi.org/10.1128/ IAl.69.4.2025-2030.2001

20. Babic MN, Zalar P, Enko B, Schroers HJ, Dzeroski S, Gunde-Cimerman N. Candida and Fusarium Species known as Opportunistic Human Pathogens from Customer-Accessible Parts of Residential Washing Machines. Fungal Biol. 2015;119(2-3):95-113. http:// doi.org/10.1016/j.funbio.2014.10.007

21. Marashdeh MQ, Gitalis R, Levesque C, Finer Y. Endodontic Pathogens Possess Collagenolytic Properties that Degrade Human Dentine Collagen Matrix. Int Endod J. 2019;52(4):416-23.

22. Martin Guerra JM, Martin Asenjo M, Rodriguez Martin C. Bacteraemia by Micrococcus luteus in an Immunocompromised Patient. Med Clin (Barc) [Internet]. 2019;152(11):469-70. http://dx.doi. org/10.1016/j.medcle.2019.04.008

23. Han SA, Shin BC, Kim H lee, Chung JH. A Case of Micrococcus luteus Relapsing Peritonitis in a Continous Ambulatory Peritoneal Dialysis Patient. Med. J. Chosun Univeristy, 2016; 41(3).

24. Guo G, Jiang J, Yang N, Wang P, Zhang L, Wang Y, et al. An investigation of sudden death in farmed infant siamese crocodiles during winter and spring in Hainan, China. Indian J. Anim. Res., 2018; 52(7): 1058-62.

25. Kushwaha AS, Pathak A, Kushwaha N. Fatal Monitor Lizard Bite: A Case Report. Int J Nurs Heal Sci. 2015;2(6):70-2. 